\title{
ORGANIC MATTER AND MORINGA LEAF EXTRACT'S EFFECTS ON THE PHYSIOLOGY AND FRUIT QUALITY OF RED SEEDLESS WATERMELON (Citrullus lanatus)
}

\author{
EFEITOS DA MATÉRIA ORGÂNICA E DO EXTRATO DA FOLHA DE MORINGA \\ SOBRE A FISIOLOGIA E QUALIDADE DO FRUTO DA MELANCIA VERMELHA \\ SEM SEMENTES (Citrullus lanatus)
}
Tahir DALORIMA ${ }^{\mathbf{1}}$; Mohammad Moneruzzaman KHANDAKER ${ }^{1 *}$; Abd Jamil ZAKARIA ${ }^{1}$; Khamsah Suryati MOHD; Mohammad Hailmi SAJILI'; Noor Afiza BADALUDDIN; Mohammed HASBULLAH ${ }^{1}$
1. School of Agriculture Science and Biotechnology, Faculty of Bioresources and Food Industry, Universiti Sultan Zainal Abidin, Besut Campus, 22200 Besut, Terengganu, Malaysia. "Corresponding Author: moneruzzaman@ unisza.edu.my

\begin{abstract}
This study was designed to assess the effects of different types of organic matter on the quality and biochemical properties of red seedless watermelon. The research was a single factor experiment, which involved six (6) treatments and four (4) replications. Watermelon grown and harvested from five (5) different organic matter sources, namely; vermicompost (VC), poultry manure (PM), cow dung (CD), goat dung (GD), and moringa leaf extract (MLE), at the rates of 10 ton, 20 ton, 30 ton, 30 ton, and $3000 \mathrm{~L} \mathrm{ha}^{-1}$, respectively, were used in this study. The results revealed that the treatment of vermicompost improved the chlorophyll content, chlorophyll fluorescence, stomatal conductance, internal carbon dioxide, net photosynthetic rate, fruit weight and mineral nutrient content of watermelon. The application of cow dung reduced the rind thickness and increased the TSS and antioxidant activity of the watermelon. The goat dung treatment significantly affected fruit size, juice content and the $\mathrm{pH}$ content of the watermelon's fruit juice. The poultry manure (PM) and moringa extract (MLE) treatments resulted in the highest anthocyanin content of all the watermelon. Although all the organic matter, in their unique ways, improved the quality of red seedless watermelon, the study shows that the vermicompost application had better growth, yield and improvement in the quality of watermelon.
\end{abstract}

KEYWORDS: Fertilizer. Quality. Biochemical property. Watermelon.

\section{INTRODUCTION}

The crop watermelon is a warm season crop. It is a member of the Cucurbitaceae family which belongs to the genus Citrullus and species Citrullus lanatus (ROSNAH et al., 2010). Even though watermelon is grown in many different countries, watermelon production is among the top major horticultural crops in Brazil, so that over the years, there has been an increase in the production area of watermelon, especially in the north and northeastern states. From 2001-2014, the area of production of watermelon in Brazil increased by $310 \%$ (ANGHINONI, 2014). Watermelons are a rich source of water and, as such, are helpful in averting dehydration. The low-calorie content of watermelon makes it the best choice for diet-conscious people. Watermelon contains mostly water (93.2\%) and other nutrients such as sugar, plus many vitamins (Thiamin, riboflavin, and niacin), (IITA, 2013). Potassium, as a macro nutrient, can be found in watermelon which is considered to help in the control of high blood pressure and perhaps avert stroke (IITA, 2013). It has also been reported that potassium helps to reduce high blood pressure and protect against the formation of kidney stones (MCDONOUGH; NGUYEN, 2012 ).

For proper growth and development, watermelon plants need heavy doses of nitrogen, and therefore, require an application of $200 \mathrm{~kg}$ per acre of nitrogen $(\mathrm{N})$. Before sowing, NPK (a mix of Nitrogen, Phosphorous, and Potassium) compound fertilizer is also required to be incorporated, followed by applications of nitrogenous fertilizers at five weeks and with regular intervals up to the anthesis stage (SCHIPPERs, 2000; RICE et al., 1986). Two inches of compost or manure over the garden area increases the growth and development of watermelon. Organic matter such as composted manure, improves nutrients for the soil, enhances structure and drainage, and balances the $\mathrm{pH}$, which indicates either acidic or alkaline conditions. OJO et al. (2014) reported that tropical soils have overwhelming problems of nutrient loss due to 
leaching, acidity, low nutrient deficiency, nutrients disproportion, and soil erosion. Therefore, for better growth and yield of watermelon fruit, it is necessary to supplement the nutrient content of the soil to meet the plant's needs. The use of organic matter such as farmyard manure, green manures, various waste products, as well as the use of compost or with the use of synthetic fertilizers, an increase in the nutrient status of the soil is achieved by boosting the soil's nutrient content (DAUDA et al., 2005).

The quality of a fruit can be categorized by features such as texture, safety, appearance, nutritional value and flavor (ROCHA et al., 2013). The production and management of fruit and vegetables, however, is strongly affected by the pulverization of inorganic fertilizers which can cause health concerns; therefore, there is a need to improve fruit and vegetable production, to give its consumers superior fruit while maintaining quality production practices (STOLZ et al., 2011). There have been serious concerns about the recent stigmatization and health implications of inorganic fertilizers; however, statistical figures (FAO, 2015) indicate that inorganic fertilizers account for more than $90 \%$ of fertilizers used by all types of farmers in developing countries. The application of organic fertilizers are essential to enhaced respiration and photosynthesis in crops. Khandaker et al. (2017) reported that the application of organic matter increased the net photosynthetic rate and transpiration of okra plants. Thus, this study aimed to evaluate the effects of organic matter on the quality and the biochemical properties of watermelon.

\section{MATERIAL AND METHODS}

\section{Experimental site, plant materials and experimental design}

The experiment was conducted at a research plot $\left(5.7471^{\circ} \mathrm{N}, 102.6101^{\circ} \mathrm{E}\right)$ at the farm of Faculty of Bioresources and Food industry, Universiti Sultan Zainal Abidin (UniSZA), Besut Campus, 22200 Besut, Terengganu, Malaysia. The area under study has an atmospheric annual temperature of 21$30{ }^{\circ} \mathrm{C}$ and relative humidity of $60-90$. The experiment was conducted between 2016 and 2017. In this research, watermelon Red Flesh Seedless Variety (F1 hybrid) was used as planting materials and different organic fertilizers viz., well decomposed cowdung, vermicompost, poultry manure, goat dung and moringa leaf extract were used as the sources of plant nutrients. The research was a single factor experiment, which involves six (6) treatments and four (4) replications. Watermelon fruits grown and harvested from different organic sources Viz; vermicompost (VC) at the rate of $10 \mathrm{t}$ $\mathrm{ha}^{-1}$, poultry manure (PM) at the rate of $20 \mathrm{t} \mathrm{ha}^{-1}$, cowdung (CD) at the rate of $30 \mathrm{t} \mathrm{ha}^{-1}$, goatdung (GD) at the rate of $30 \mathrm{t} \mathrm{ha}^{-1}$, moringa leaf extract (MLE) at the rate of $3000 \mathrm{Lha}^{-1}$ (diluted volume) were used in this study. Four fruits from each replication were randomly selected for measurement of growth and fruit quality parameters.

\section{Measurements of physiological properties}

The chlorophyll content of the watermelon leaves was determined using a Konica Minolta Chlorophyll Meter (Model: SPAD 502Plus). Three fully matured leaves from the middle of vine randomly selected and were cleaned for data recording. The chlorophyll content was measured around $1 \mathrm{pm}$ and four times during the experimental period. The data was shown as SPAD value index. A portable CI-340 handheld Photosynthesis System (Bio-Science, USA) was used for the measurement of photosynthetic characteristics viz; net photosynthetic rate, transpiration rate, stomatal conductance and internal carbon dioxide concentration $\left(\mathrm{IntCO}_{2}\right)$ were measured three times during plant growth and development. Photosynthetic characteristics measurements were carried out according to Khandaker et al. (2012). A Plant Efficiency Analyzer (Hansatech Instruments Ltd., England) was used to measure chlorophyll fluorescence and the photosynthetic yield of treated and untreated watermelon plants

\section{Measurement of fruit size, weight and rind thickness}

The length and diameter of the watermelon fruit was measured manually by using a flexible tape. Watermelon was positioned vertically at its most stable position and diameter of the fruit was recorded. The length of the fruit was determined by measuring the distance between the top portion and the bottom portion (YAU et al. 2010). The weight of the whole watermelon fruit was recorded using an electronic weighing balance (Model: Mettle PJ3000, Japan). The thickness of the rind was measured with the aid of an electronic digital vernier calipers and the average value was recorded in centimeter $(\mathrm{cm})$.

\section{Measurement of juice contente}

The total moisture component of the samples is described as the juice content of the sample. Crucibles were oven dried at $90^{\circ} \mathrm{C}$ for 30 min and transferred into desiccators to cool. After cooling, the cubes of watermelon fruit of the diameter $5 \mathrm{~mm}$ x $5 \mathrm{~mm}$ x $5 \mathrm{~mm}$ size. Each sample 
was weighed in the crucible and oven dried at $110^{\circ} \mathrm{C}$ to a constant weight. The percentage juice content of each sample was then calculated as follows:

Juice content $(\%)=\frac{w_{3}-w_{1}}{w_{2}-w_{3}} \times 100$

where; W1 = Weight of Crucible, W2 = Weight of empty Crucible and Sample before drying, W3 = Weight of Crucible and Sample after drying

\section{Determination of $\mathrm{pH}$ and ash}

A glass electrode $\mathrm{pH}$ meter was used to determine the fruit juice $\mathrm{pH}$ after extracting and sieving the juice of watermelon. Buffers of $\mathrm{pH} 4.0$ and 7.0 were being used to calibrate the $\mathrm{pH}$ meter. Ash of a biological material is an methodical term for the organic residue that remains after the organic matter has been burnt off (INUWA et al. 2011). The percentage of ash was then calculated using the formula below:

Crude $A s h(\%)=\frac{w_{3}-w_{1}}{w_{2}-w_{1}} \times 100$

where; W1 = Weight of Crucible , W2 = Weight of Crucible and Sample before ashing, W3 = Weight of Crucible and Sample after ashing

Determination of fruit minerals (K, Fe, Na, Mg, $\mathrm{Ca}$ and $\mathrm{Cu}$ ), TSS and anthocyanin content

In this study, there were six kinds of minerals present in watermelon fruit that were analysed; including Potassium (k), Iron (Fe), Sodium (Na), Magnesium (Mg), Calcium (Ca) and Cupper $(\mathrm{Cu})$. The method used to analyse the mineral content was described by Jackson (1973). The solutions including watermelon flesh were allowed to stand overnight, and then filtered through a dry filter paper to remove excess silica without washing. The solution containing samples were retained and used for the analysis of minerals against the reagent blank by Atomic Absorption Spectrophotometer (AAS). Three replicates of samples from each treatment were used, and the average was computed, results were expressed as $\mathrm{mg} \mathrm{g}^{-1}$. A digital hand refractometer (Atago Co. LTD., Tokyo, Japan) was used to evaluate the total soluble solids (TSS) content and the result was expressed as ${ }^{\circ}$ Brix. Total anthocyanin contents of watermelon extracts were determined by the $\mathrm{pH}$ differential method (RODRIGUEZ et al. 1999).

\section{Determination of DPPH free-radical scavenging activity}

To determine the quantitative measurement of radical scavenging properties, the solution of 50 $\mu \mathrm{l}$ of methanolic extract samples (or $80 \% \mathrm{MeOH}$ as a blank) and $1 \mathrm{ml}$ of $0.04 \%(\mathrm{w} / \mathrm{v})$ solution of DPPH in methanol. A standard antioxidant (Quercetin) was used for comparison or as a positive control (BLOIS 1958). Discoloration was determined at $517 \mathrm{~nm}$ after incubations for $30 \mathrm{~min}$. The actual decrease in absorption induced by the test compounds was compared with the positive controls.

\section{Statistical analysis}

The experiment was carried out according to Randomized Complete Block Design (RCBD) with four replications. The data obtained was analysed using SAS (Version 9.3) software. A one way repeated ANOVA was applied to evaluate any significant differences within the parameters studied in this experiment. Least significant difference (LSD) test was used to compare different treatments whenever ANOVA showed significant differences among means.

\section{RESULTS}

\section{Chlorophyll Content, Photosynthetic Characteristics and Photosynthetic Yield of Watermelon}

The chlorophyll content of the watermelon crops was measured at intervals of $21,42,63$, and 84 days (DAT) after transplanting the nursery stock to separate fields with the 5 different organic matter treatments applied. At 21 and 45 days, the different treatments did not produced any significant effect on the chlorophyll content of watermelon leaves (Table 1). The VC shows a greater impact than CD, GD, MLE, and a control application, but, VC is not significantly different from poultry manure. The chlorophyll content of PM, CD, and GD are not significantly different from each other, however, the control treatment and MLE show the lowest values of 41 and 41, respectively, which are not statistically different from GD (47.2 SPAD) at day 84. The different organic matter and MLE produced a significant effect on the net photosynthetic rate of the watermelon at 45 and 75 days. Two weeks after planting, the different treatments did not produce any significant effect on the net photosynthetic rate (Table 1). At 45 days, the plants treated with CD produced the highest net photosynthetic rate $(18.65$ $\mu \mathrm{m} / \mathrm{m}^{2} / \mathrm{s}$ ), followed by GD, PM and other treatments, while the control plants showed the lowest net photosynthetic rate $\left(13.92 \mu \mathrm{m} / \mathrm{m}^{2} / \mathrm{s}\right)$. Subsequently, net photosynthetic rates measured at day 75 indicated that $C D$ was statistically different from the control treatment. 
Table 1. Influence of organic matters and moringa leaf extract on the physiological properties of red seedless watermelon

\begin{tabular}{ccccccc}
\hline \multicolumn{3}{c}{ Chlorophyll content } \\
\hline \multicolumn{7}{c}{ Days After Transplanting (DAT) } \\
21 & 42 & 63 & 84 & 14 & 45 & 75 \\
\hline $34.25 \mathrm{a}$ & $37.05 \mathrm{a}$ & $40.75 \mathrm{~cd}$ & $41.00 \mathrm{c}$ & $9.27 \mathrm{a}$ & $13.92 \mathrm{~b}$ & $20.12 \mathrm{c}$ \\
$28.47 \mathrm{a}$ & $47.92 \mathrm{a}$ & $57.25 \mathrm{a}$ & $61.37 \mathrm{a}$ & $8.52 \mathrm{a}$ & $16.55 \mathrm{ab}$ & $20.72 \mathrm{bc}$ \\
$35.07 \mathrm{a}$ & $46.87 \mathrm{a}$ & $51.75 \mathrm{ab}$ & $52.40 \mathrm{~b}$ & $8.50 \mathrm{a}$ & $16.84 \mathrm{ab}$ & $21.11 \mathrm{abc}$ \\
$30.80 \mathrm{a}$ & $42.30 \mathrm{a}$ & $45.90 \mathrm{bc}$ & $54.12 \mathrm{~b}$ & $9.19 \mathrm{a}$ & $18.65 \mathrm{a}$ & $22.38 \mathrm{a}$ \\
$29.15 \mathrm{a}$ & $47.30 \mathrm{a}$ & $45.50 \mathrm{c}$ & $47.22 \mathrm{bc}$ & $8.69 \mathrm{a}$ & $16.50 \mathrm{ab}$ & $21.68 \mathrm{ab}$ \\
$33.22 \mathrm{a}$ & $37.00 \mathrm{a}$ & $38.75 \mathrm{~d}$ & $41.00 \mathrm{c}$ & $8.57 \mathrm{a}$ & $16.37 \mathrm{ab}$ & $20.85 \mathrm{bc}$ \\
13.13 & 16.26 & 5.90 & 7.17 & 1.80 & 3.73 & 1.4 \\
\hline
\end{tabular}

Mean values with the same letters within the same column are not significantly different at $\mathrm{p} \leq 0.05$. CNT; control, VC; vermicompost, PM; poutry manure, CD; cowdung, GD; Goatdung, MLE; moringa leaves extract, LSD; least significant difference.

The transpiration rate was measured at 14 , 45 and 75 days (DAT) with results observed at 14 DAT for all the treatments statistically the same. Results show the VC, PM, GD, and MLE are not statistically different from each other than at 45 DAT. However, CD with the highest value of net transpiration $\left(2.85 \mathrm{mmol} / \mathrm{m}^{2} / \mathrm{s}\right)$ is statistically different from all other organic matter and the control matter which has the least value of net transpiration $\left(1.45 \mathrm{mmol} / \mathrm{m}^{2} / \mathrm{s}\right)$ at $45 \mathrm{DAT}$. Results recorded at 75 days after transplant indicate that $\mathrm{PM}, \mathrm{CD}$, and GD, with values of $1.74,1.71$ and 1.74 $\mathrm{mmol} / \mathrm{m}^{2} / \mathrm{s}$, respectively, are significantly different from the control with the lowest transpiration rate value at $1.28 \mathrm{mmol} / \mathrm{m}^{2} / \mathrm{s}$ (Table 1 ). The stomatal conductance of watermelon plants was recorded at 14,45 and 75 DAT. Results indicate that all of the treatments did not vary significantly at 14 DAT. Vermicompost produced the highest value of stomatal conductance $\left(0.14 \mathrm{mmol} / \mathrm{m}^{2} / \mathrm{s}\right)$ at $45 \mathrm{DAT}$ which is significantly higher than the other treatments and the control. Moreover, results observed at 75 DAT show that stomatal conductance of treated and untreated plants did not vary significantly from each other (Table 2).

Table 2. Influence of organic matters and moringa leaf extract on the stomatal conductance, Internal $\mathrm{CO}_{2}$ and photosynthetic yield of red seedless watermelon

\begin{tabular}{lccccccccc}
\hline & \multicolumn{3}{c}{ Stomatal Conductance } & \multicolumn{4}{c}{ Internal CO } & \multicolumn{4}{c}{$\begin{array}{l}\text { Photosynthetic } \\
\text { Yield }\end{array}$} \\
\cline { 2 - 11 } & \multicolumn{4}{c}{} & \multicolumn{4}{c}{ Days After Transplanting (DAP) } \\
& 14 & 45 & 75 & 14 & 45 & 75 & 14 & 45 & 75 \\
CNT & $0.03 \mathrm{a}$ & $0.05 \mathrm{c}$ & $0.12 \mathrm{a}$ & $3.79 \mathrm{a}$ & $7.68 \mathrm{c}$ & $5.78 \mathrm{a}$ & $0.809 \mathrm{a}$ & $0.810 \mathrm{a}$ & $0.802 \mathrm{c}$ \\
VC & $0.03 \mathrm{a}$ & $0.14 \mathrm{a}$ & $0.12 \mathrm{a}$ & $3.45 \mathrm{a}$ & $8.64 \mathrm{abc}$ & $7.53 \mathrm{a}$ & $0.810 \mathrm{a}$ & $0.815 \mathrm{a}$ & $0.827 \mathrm{a}$ \\
PM & $0.03 \mathrm{a}$ & $0.07 \mathrm{bc}$ & $0.07 \mathrm{a}$ & $3.94 \mathrm{a}$ & $8.09 \mathrm{bc}$ & $6.35 \mathrm{a}$ & $0.815 \mathrm{a}$ & $0.815 \mathrm{a}$ & $0.827 \mathrm{a}$ \\
CD & $0.03 \mathrm{a}$ & $0.10 \mathrm{ab}$ & $0.13 \mathrm{a}$ & $3.49 \mathrm{a}$ & $11.33 \mathrm{a}$ & $7.96 \mathrm{a}$ & $0.817 \mathrm{a}$ & $0.815 \mathrm{a}$ & $0.827 \mathrm{a}$ \\
GD & $0.03 \mathrm{a}$ & $0.07 \mathrm{bc}$ & $0.07 \mathrm{a}$ & $4.07 \mathrm{a}$ & $10.69 \mathrm{ab}$ & $7.13 \mathrm{a}$ & $0.815 \mathrm{a}$ & $0.810 \mathrm{a}$ & $0.815 \mathrm{~b}$ \\
MLE & $0.03 \mathrm{a}$ & $0.06 \mathrm{bc}$ & $0.08 \mathrm{a}$ & $3.77 \mathrm{a}$ & $9.57 \mathrm{abc}$ & $6.79 \mathrm{a}$ & $0.812 \mathrm{a}$ & $0.812 \mathrm{a}$ & $0.812 \mathrm{bc}$ \\
LSD & 0.016 & 0.49 & 0.17 & 2.27 & 2.73 & 3.38 & 0.014 & 0.015 & 0.017 \\
\hline
\end{tabular}

Mean values with the same letters within the same column are not significantly different at $\mathrm{p} \leq 0.05$. CNT; control, VC; vermicompost, PM; poutry manure, CD; cowdung, GD; Goatdung, MLE; moringa leaves extract, LSD; least significant difference

Recorded results of the internal carbon dioxide $\left(\mathrm{CO}_{2}\right)$ concentrations in the watermelon was influenced by different organic matter and MLE at 14, 45 and 75 DAT. Results related to internal $\mathrm{CO}_{2}$ concentration obtained at 14 DAT are not statistically different from each other. At 45 DAT, $\mathrm{CD}$ has the highest value of internal $\mathrm{CO}_{2}(11.33$ $\mu \mathrm{m} / \mathrm{mol}$ ) followed by GD and MLE with internal $\mathrm{CO}_{2}$ values of 10.69 and $9.57 \mu \mathrm{m} / \mathrm{mol}$, respectively, which is significantly higher than the control with an internal $\mathrm{CO}_{2}$ value of $7.68 \mu \mathrm{m} / \mathrm{mol}$. However, all of the values of internal $\mathrm{CO}_{2}$ concentration among treatments at 75DAT vary insignificantly. Photosynthetic yield (Fv/Fm) was recorded at 14, 45 and 75 days after transplant, results obtained indicate that at 14 and 45 DAT no significant differences were observed amongst the treatments and control. However at 75 DAT VC, PM, and CD had the highest values at $0.82,0.82$ and $0.82 \mathrm{~F}_{\mathrm{v}} / \mathrm{F}_{\mathrm{m}}$, respectively, and are statistically significant when 
compared to control with the least mean value of $0.80 \mathrm{~F}_{\mathrm{v}} / \mathrm{F}_{\mathrm{m}}$. Moreover, GD and MLE are not statistically different from the control at 75 DAT.

\section{Fruit weight and fruit Size}

The results show that organic manure and MLE produced a significant effect on watermelon yield. Fruit weight (yield) was highest in plots treated with VC $\left(285 \mathrm{t} \mathrm{ha}^{-1}\right)$, followed by PM, and then the other treatments (Figure 1 \& Figure 2 A below). The lowest fruit weight was recorded in the control plot $\left(106 \mathrm{t} \mathrm{ha}^{-1}\right)$. The watermelons' size was significantly affected by organic matter and the moringa leaf extract treatments (Figure 1). Results indicate that GD had the highest length to diameter ratio (1.033) followed by MLE (1.032), which were significantly higher than the control ratio (1.024) with the lowest length to diameter ratio.

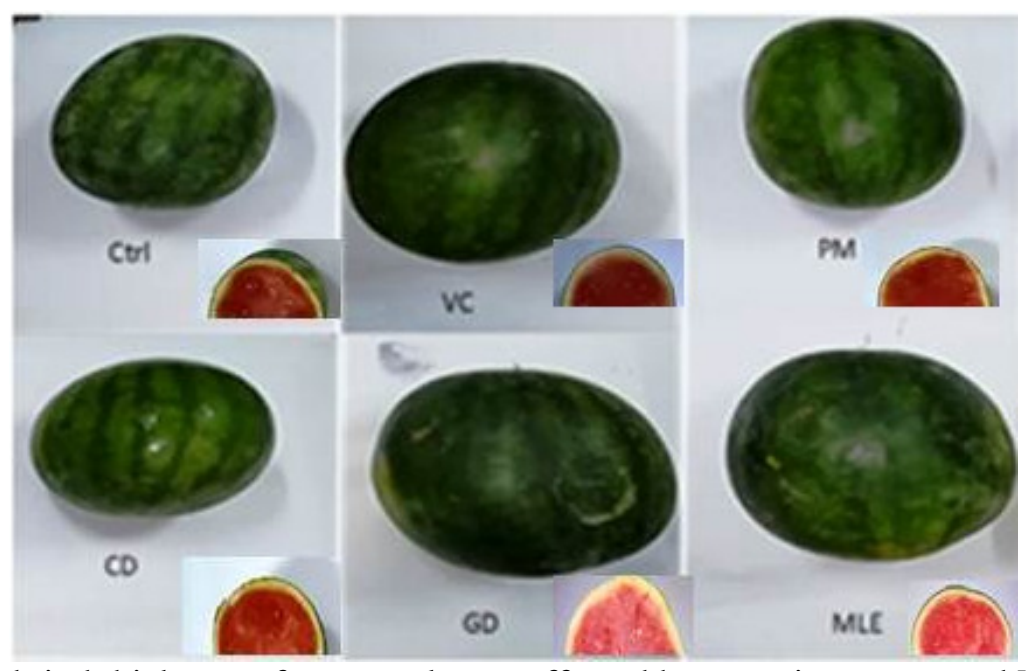

Figure 1. Fruit size and rind thickness of watermelon as affected by organic matters and MLE

\section{Rind thickness and juice contente}

The juice content is the percentage of water contained in the watermelon as a percentage $(\%)$. From the results obtained, GD had the highest juice content $(94.9 \%)$ and PM had the lowest juice content (93\%) (Figure 1), however, all of the treated and untreated plants are not statistically different from each other at $\mathrm{P} \leq 0.05$. From the Rind Thickness results shown in Figure 2 (D), it is observed that $\mathrm{CD}(1.12 \mathrm{~cm})$ has the lowest rind thickness which varies significantly from the Control $(1.55 \mathrm{~cm})$. However, VC, PM, GD, and MLE did not vary from either the control or $\mathrm{CD}$ at $\mathrm{P}$ $\leq 0.05$.

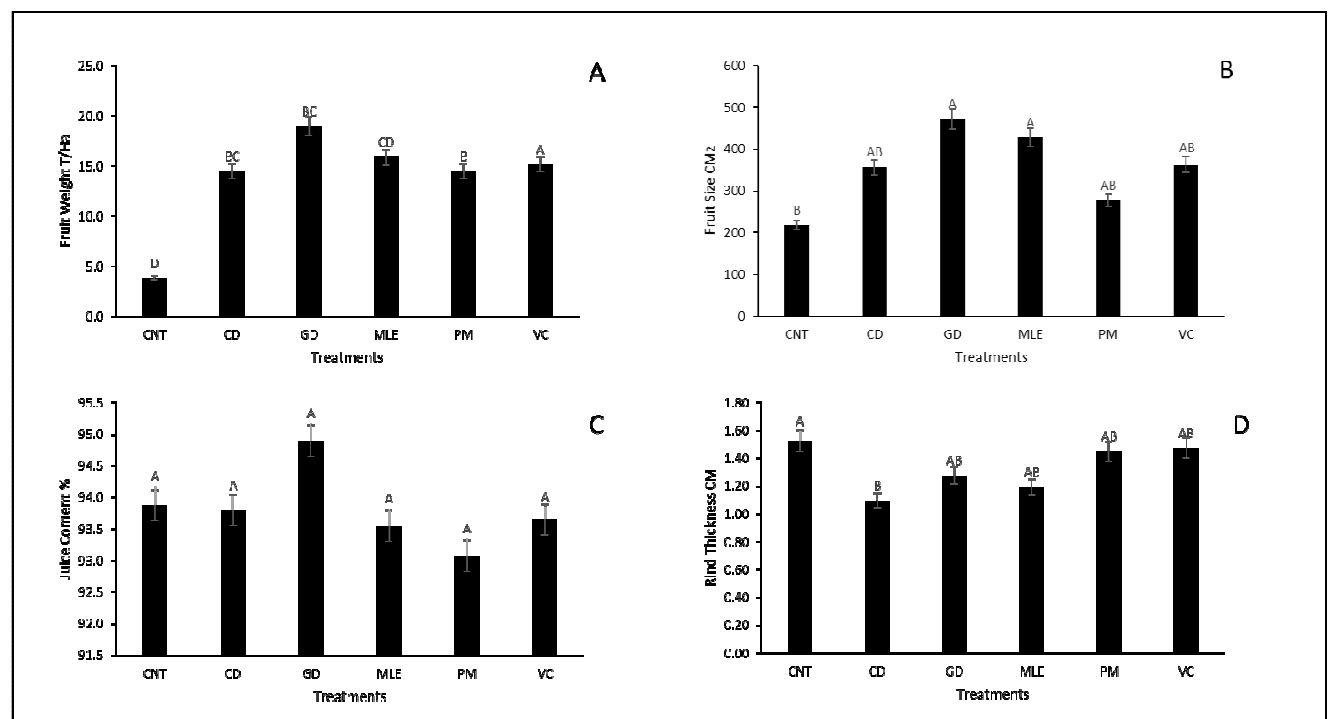

Figure 2. Effects of organic matters on (A) Fruit weight, (B) Fruit size, (C) Juice content, (D) Rind thickness of red-seedless watermelon. Bars indicate $\pm \mathrm{SE}$ and different letters represent the statistical significance at $\mathrm{p}<0.05$. CNT; control, VC; vermicompost, PM; poutry manure, CD; cowdung, GD; Goatdung, MLE; moringa leaves extract. 


\section{Anthocyanin content and pH of the fruit juice}

The results obtained for anthocyanin content of watermelon treated with different organic matter shows that poultry manure (PM), and moringa extract (MLE), had the highest anthocyanin content with values of $0.255 \mathrm{mg} / \mathrm{g}$ and $0.2544 \mathrm{mg} / \mathrm{mg}$, respectively, which are statistically different $(\mathrm{P} \leq$ 0.05 ) from the other treatments, as well as the control. Although (CD) had the lowest anthocyanin content $(0.094 \mathrm{mg} / \mathrm{g})$, it is not significantly different from the control, vermicompost (VC) or goat dung (GD) (Figure 3A). Results from figure 3B indicate that the fruit juice $\mathrm{pH}$ was highest in GD (5.66) which is significantly higher than the control (5.25) with the lowest $\mathrm{pH}$ value. However VC, PM, CD, and MLE are not statistically different from either GD or the control.

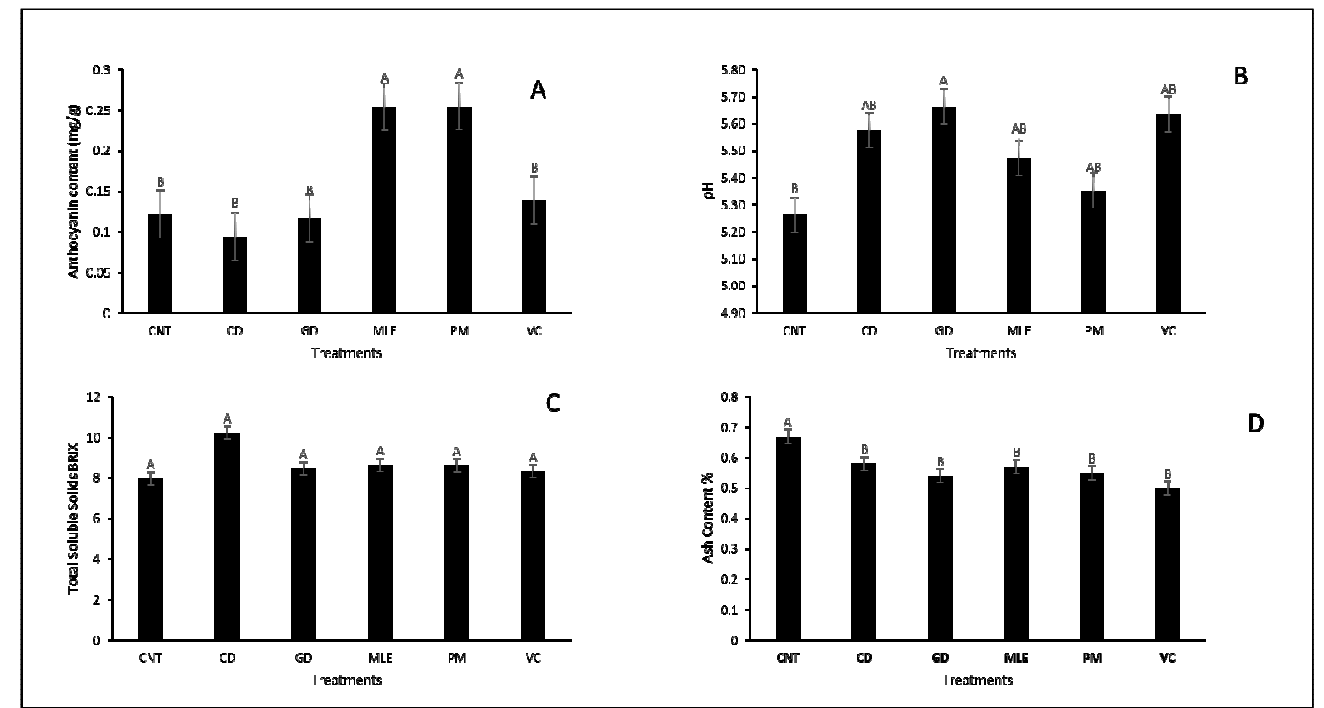

Figure 3. Effects of organic matters on (A) Anthocyanin content, (B) $\mathrm{pH}$, (C) Total soluble solids, (D) Ash content of red-seedless watermelon. Bars indicate \pm SE and different letters represent the statistical significance at $\mathrm{p}<0.05$. CNT; control, VC; vermicompost, PM; poutry manure, CD; cowdung, GD; Goatdung, MLE; moringa leaves extract.

\section{Total Soluble Solids (TSS) and Ash contente}

Data recorded for TSS did not vary significantly amongst treatments $(\mathrm{P} \leq 0.05)$, however watermelon grown from the cow dung treatment had the highest TSS content $\left(10.22^{\circ}\right.$ Brix $)$, and the control had the lowest TSS content (7.9 ${ }^{\circ}$ Brix) (Figure 3B). The percentage of ash content in the watermelon was measured and recorded showing that the watermelon from the vermicompost treatment had the least ash content $(0.51 \%)$ followed by goat dung $(0.54 \%)$, but the control had the highest ash content percentage with a value of $0.67 \%$, however, there is not a statistical difference between all of the treated plants and the control at $\mathrm{P}$ value of $<0.05$ (Figure 3D).

\section{Antioxidant activity}

The radical scavenging activity of watermelon fruit extract, as shown in Table 3, expresses the percentage of inhibation of the initial DPPH absorption by the tested compound. The reaction mixture contained $50 \mu \mathrm{l}$ of methanolic extract samples as a blank. The data from the table reports that at concentrations of $50 \mu \mathrm{g} / \mathrm{ml}$, the control had the least mean value of 31.86 , moringa biostimulant at 48.81 , and cow dung at 47.72 , did not vary statistically from the standard quercetin (51.36). Results of $100 \mu \mathrm{g} / \mathrm{ml}$ concentrations show that all the treatments are significantly different from the lowest control (56.03) and the highest quercetin (82.56), however poultry manure (67.7) did not vary statistically $(\mathrm{p} \leq 0.05)$ from goat dung (65.48). 
Table 3. Effects of organic matters on antioxidant activity values of watermelon fruits at different concentrations $(50$ and $100 \mu \mathrm{g} / \mathrm{ml})$

\begin{tabular}{lll}
\hline Treatments & \multicolumn{2}{c}{ Inhibition (\%) } \\
\cline { 2 - 3 } & $\mathbf{5 0 \mu \mathrm { g } / \mathbf { m l }}$ & $\mathbf{1 0 0} \boldsymbol{\mu g} / \mathbf{m l}$ \\
\hline CNT & $31.86 \pm 0.72 \mathrm{e}$ & $56.03 \pm 1.28 \mathrm{f}$ \\
VC & $46.02 \pm 0.43 \mathrm{c}$ & $62.06 \pm 0.74 \mathrm{e}$ \\
PM & $47.22 \pm 0.45 \mathrm{bc}$ & $67.7 \pm 0.81 \mathrm{~d}$ \\
CD & $47.72 \pm 0.65 \mathrm{ab}$ & $71.75 \pm 0.32 \mathrm{c}$ \\
GD & $40.5 \pm 0.43 \mathrm{~d}$ & $65.48 \pm 0.58 \mathrm{~d}$ \\
MLE & $48.81 \pm 0.58 \mathrm{ab}$ & $78.3 \pm 0.32 \mathrm{~b}$ \\
Quercetin (standard) & $51.36 \pm 0.42 \mathrm{a}$ & $82.56 \pm 0.49 \mathrm{a}$ \\
LSD & 2.656 & 3.309 \\
C.V & 2.57 & 2.08 \\
\hline
\end{tabular}

Mean values with the same letters within the same column are not significantly different at $\mathrm{p} \leq 0.05$. CNT; control, VC; vermicompost, PM; poutry manure, CD; cowdung, GD; Goatdung, MLE; moringa leaves extract, LSD; least significant difference, CV; coefficient of variability.

\section{Nutrient Content and Its Correlation among Parameters}

Results in Table 4, indicate the nutrient content of watermelon pulp. The nutrients measured were Potassium $(\mathrm{K})$, Iron $(\mathrm{Fe})$, Sodium $(\mathrm{Na})$, Magnesium (Mg), Calcium (Ca) and Copper $(\mathrm{Cu})$. Results show that poultry manure had the highest mean value $(56.045 \mathrm{mg} / \mathrm{g})$ of potassium which is significantly different from the least performing treatment, which was the control treatment (44.865 $\mathrm{mg} / \mathrm{g}$ ). Iron content did not vary significantly between the treatments. Moringa leaf extract had the highest sodium content $(21.338 \mathrm{mg} / \mathrm{g})$, however it differed from cow dung $(17.735 \mathrm{mg} / \mathrm{g})$ and goat dung $(15.730 \mathrm{mg} / \mathrm{g})$. Moreover, the control treatment recorded the least sodium content $(18.720 \mathrm{mg} / \mathrm{g})$. The magnesium content measurement showed that vermicompost had the highest mean value $(0.211 \mathrm{mg} / \mathrm{g})$ and was statistically different from goat dung which had the least magnesium content $(0.183 \mathrm{mg} / \mathrm{g})$. The calcium content measurement shows the control had the highest mean value $(0.155 \mathrm{mg} / \mathrm{g})$, however, no significant difference was observed between the treated fruits. The analyzed results for copper indicate that moringa extract had the highest copper content $(0.234 \mathrm{mg} / \mathrm{g})$ followed by goat dung, then vermicompost with mean values of 0.229 and 0.220 $\mathrm{mg} / \mathrm{g}$, respectively, and are statistically higher than control $(0.161 \mathrm{mg} / \mathrm{g})$.

Table 4. Effects of organic matters and moringa leaf extract on the nutrient content of watermelon fruits

\begin{tabular}{lllllll}
\hline \multirow{2}{r}{ Treatments } & $\mathbf{K}$ & $\mathbf{F e}$ & $\mathbf{N a}$ & $\mathbf{M g}$ & $\mathbf{C a}$ & $\mathbf{C u}$ \\
\hline CNT & $44.865 \mathrm{bc}$ & $0.222 \mathrm{a}$ & $18.720 \mathrm{ab}$ & $0.223 \mathrm{ab}$ & $0.155 \mathrm{a}$ & $0.161 \mathrm{~b}$ \\
VC & $51.180 \mathrm{ab}$ & $0.230 \mathrm{a}$ & $14.940 \mathrm{~b}$ & $0.211 \mathrm{ab}$ & $0.114 \mathrm{a}$ & $0.220 \mathrm{a}$ \\
PM & $56.045 \mathrm{a}$ & $0.218 \mathrm{a}$ & $14.010 \mathrm{~b}$ & $0.242 \mathrm{a}$ & $0.141 \mathrm{a}$ & $0.203 \mathrm{ab}$ \\
CD & $50.323 \mathrm{ab}$ & $0.216 \mathrm{a}$ & $17.735 \mathrm{ab}$ & $0.217 \mathrm{ab}$ & $0.153 \mathrm{a}$ & $0.199 \mathrm{ab}$ \\
GD & $41.133 \mathrm{c}$ & $0.210 \mathrm{a}$ & $15.730 \mathrm{ab}$ & $0.183 \mathrm{~b}$ & $0.140 \mathrm{a}$ & $0.229 \mathrm{a}$ \\
MLE & $32.810 \mathrm{~d}$ & $0.211 \mathrm{a}$ & $21.338 \mathrm{a}$ & $0.199 \mathrm{ab}$ & $0.147 \mathrm{a}$ & $0.234 \mathrm{a}$ \\
LSD & 6.6488 & 0.048 & 5.618 & 0.051 & 0.1174 & 0.055 \\
CV & 6.4423 & 9.803 & 14.640 & 11.539 & 36.906 & 11.847 \\
\hline
\end{tabular}

Mean values with the same letters within the same column are not significantly different at $\mathrm{p} \leq 0.05$. CNT; control, VC; vermicompost, PM; poutry manure, CD; cowdung, GD; Goatdung, MLE; moringa leaves extract, LSD; least significant difference, $\mathrm{CV}$; coefficient of variability.

From the correlation matrix below, it was reported that the chlorophyll content and transpiration rate have a positive, significant, correlation to net photosynthesis (Table 5). It is furthermore sufficient to report that internal $\mathrm{CO}_{2}$ had a positive relationship on the net photosynthesis of watermelon plants grown in BRIS soil amended with organic matter and moringa leaf extract. Photosynthetic yield correlates to a transpiration rate at $\mathrm{p}$ level of 0.05 . The number of fruit statistically correlates to the net photosynthesis, transpiration rate, internal $\mathrm{CO}_{2}$, and chlorophyll fluorescence. On 
the other hand, fruit weight significantly correlates

to the chlorophyll content of watermelon leaves
(Table 5).

Table 5. Correlation between physiological and qualitative properties of watermelon

\begin{tabular}{|c|c|c|c|c|c|c|c|c|c|c|}
\hline PARAMETERS & $\begin{array}{c}\text { Chlorophyll } \\
\text { Content }\end{array}$ & $\begin{array}{c}\text { Net } \\
\text { Photosynthesis }\end{array}$ & $\begin{array}{c}\text { Transpiration } \\
\text { Rate }\end{array}$ & $\begin{array}{c}\text { Stomatal } \\
\text { Conductance }\end{array}$ & $\begin{array}{c}\text { Internal } \\
\mathrm{CO} 2\end{array}$ & $\begin{array}{c}\text { Photosynthetic } \\
\text { Yield }\end{array}$ & $\begin{array}{l}\text { No of } \\
\text { Fruits }\end{array}$ & $\begin{array}{c}\text { Fruit } \\
\text { Weight }\end{array}$ & $\begin{array}{c}\text { Fruit } \\
\text { Size }\end{array}$ & $\begin{array}{c}\text { Juice } \\
\text { Content }\end{array}$ \\
\hline Chloro. Cont. & 1 & & & & & & & & & \\
\hline Net Phot. & .315 & 1 & & & & & & & & \\
\hline Transp. Rate & .522 & $.874^{*}$ & 1 & & & & & & & \\
\hline Stomatal Cond. & .647 & .135 & .041 & 1 & & & & & & \\
\hline Internal $\mathrm{CO}_{2}$ & .081 & $.861^{*}$ & .760 & .060 & 1 & & & & & \\
\hline Photosyn Yield & .754 & .796 & $.865^{*}$ & .340 & .475 & 1 & & & & \\
\hline No of Fruits & .537 & $.909^{*}$ & $.893^{*}$ & .397 & $.839^{*}$ & $.835^{*}$ & 1 & & & \\
\hline Fruit Weight & $.958^{* *}$ & .287 & .555 & .633 & .140 & .717 & .586 & 1 & & \\
\hline Fruit size & .067 & .471 & .663 & -.140 & .763 & .255 & .611 & .261 & 1 & \\
\hline Juice Content & -.215 & .075 & .019 & -.040 & .490 & -.338 & .079 & -.205 & .462 & 1 \\
\hline
\end{tabular}

\section{DISCUSSION}

Chlorophyll content in the leaves of plants correlates to the amount of nutrients absorbed by the crop from its growth medium, which translates into the physiological performance of the plant. The chlorophyll content of the watermelon crops was higher (40 - 60 SPAD value) at 63 and 84 DAT, since the accumulation of chlorophyll on these days was within the required value for watermelon crops (TADMOR et al. 2010) . The chlorophyll content of watermelon crops varies from 30 to 50 SPAD value (INTHICHACK et al. 2014). The chlorophyll content of vegetable crops increases at the peak growth stage (MALGORZATA et al. 2010). The opening and closure of the stomata will affect photosynthetic $\mathrm{CO}_{2}$ fixation in mesophyll tissues which has also been shown to be affected by organic matter in the soil. In this study, results indicate that vermicompost treatment improves the chlorophyll content in watermelon leaves. Organic matter could significantly increase the cholorophyll content. In spider plant leaves the chlorophyll content was increased with subsequent increments of nitrogen fertilizers (ZHANG et al. 2011). This might be the connection between the efficient assimilation, and absorption, of nitrogen by the plant which serves as a constituent of chlorophyll in the plant tissue. In this study, a significant increase in net photosynthesis and the transpiration rate was observed in all of the organic matter and the moringa leaf extract treated plants. A late decline was recorded in the transpiration rate which is a result of the reduction of $\mathrm{CO}_{2}$ fixation in leaf mesophyll tissues induced by stomatal closure. A decrease in transpiration rate occurs as a marigold plant advances into its late stage (SINGH et al. 2015). The increased organic matter, which contains magnesium and other nutrient elements, might have helped chlorophyll synthesis which in turn increased the rate of photosynthesis. Organic matter can increase root growth and holds a large quatity of water for use by the plant roots. This improves the root system of watermelon plants which may absorb larger quatities of water and increase transpiration more than the control plants.

Results indicate that stomatal conductance at 45 DAT was higher in vermicompost treatment, then, later declined at 75 DAT which was because of stomatal closure in the leaves' mesophyll, an occurance related to its loss of chlorophyll pigmatations. These observations conform with findings of Efthimiadou et al., (2010), but are contradictory to Selvaraju; Iruthayaraj, 1995. Internal $\mathrm{CO}_{2}$ assimilation was higher at 45 days which correlates to the chlorophyl content of the crops and translates to higher chemical activity in the leaves of watermelon plants.

Photosynthetic yields are a result of energy absorbed from the sun that was not used for heat dissipation or photosynthetic reactions. The results of this study indicate that photosynthetic yield (fv/fm) was higher in all of the treated plants when compared to the control treated plants during all successive test days after transplant. Similar effects were observed which resulted in an increase in the 
antenna pigment levels and the excitation efficiency of trapping at the centers of active PS-II (MONERUZZAMAN et al., 2013). Both strawberry and apple plants perform better in terms of photosynthetic efficiency when treated with organic manure as compared to chemical fertilizers (BAKER; ROSENQVIST 2004). A decrease in the $\mathrm{F}_{\mathrm{v}} / \mathrm{F}_{\mathrm{m}}$ ratio is a consistent sign of photoinhibition which shows that these crops are more light sensitive. This is because photosynthetic yield ratios indicate the photochemical efficiency of crops, so that, a greater reduction in this parameter occurs in plants grown in higher $\mathrm{O}_{2}$ concentration. A minimum level of fluorescence content caused the state of the leaves to remain unchanged in all treatments, indicating that organic matter has an effect on improving the photosynthetic yield of watermelon.

Fruit weight measurements indicate that vermicompost produced the highest weight fruit. Vermicompost at 15 ton $\mathrm{ha}^{-1}$ had a higher fruit weight when compared with treatments of organic manure at 15 ton ha ${ }^{-1}$ (RAKESH et al. 2014). The control treatment produced the lowest weight fruit. This is possible because of low nitrogen content which produces poor fruit settings and, as a result, the formation of smaller fruit (JOHN et al., 2004). It is sufficient to report that all of the organic matter performed as expected. These results were also in concordance with similar studies, which reported that olive fruit flesh weight varied greatly according to fertilization with various organic matter (HEGAZI et al. 2007). Incremental changes of average fruit weight could be due to better nutrient content of the amended soils with organic matter. The reason for improved fruit weight could be attributed to the solubilization effect of crop nutrients, with the addition of organic fertilizers, resulting in an increased uptake of essential nutrients (SENDURKUMARAN et al., 1998). These observations are in harmony with those of Silvia et al. (2007).

Results indicate that goat dung, followed by moringa extract, had the biggest fruit sizes and this was significantly different from the control treatments. During the developmental period of the fruit sets, nutrients in organic matter increase carbohydrate availability and photosynthesis which causes cell enlargement. $\mathrm{GA}_{3}$ stimulates cell expansion during the fruit set and the developmental stages (KHANDAKER et al., 2013). RAPHAEL et al. (2007) reported that exogenous applications of biostimulants raised the carbohydrate levels in fruit and increased fruit size. Moringa biostimulant improves fruit size which could be because moringa extracts have been shown to include zeatin, a cytokinin related hormone (FUGLIE 2000). Poultry manure also increases fruit size because the fruit is positively influenced by adequate supplies of nitrogen (ALABI 2006). Watermelon crops have an indeterminate growth pattern so the fruit develops progressively on the same plant due to continuous flowering. Competition for available nutrients amongst the fruit has a direct effect on the fruit size of the watermelon (ALI; KELLY, 1992).

The watermelon rind is the area of whitish flesh between the colored flesh of the edible fruit and the exterior skin. From the results measured, it is observed that $\mathrm{CD}$ has the thinnest rind. Cattle manure applications led to thinner fruit rind in watermelon cultivation (AUDI et al. 2013). But in other studies it was reported that the gene of a watermelon fruit has a direct correlation to the fruit rind thickness (PORTER, 1941). Rind thickness seems to be propotional to the fruit variety since Yellow Crimson resulted in the highest value of rind thickness followed by the Giza hybrid and the thinnest value in the Envy variety (ABDELMAWGOUD et al., 2010). A thicker rind in the control treated watermelon could be attributed to a lower nutrient and moisture content in the soil which hinders fruit biomass formation. This argument is in agreement with a similar study which reported that soil amended with organic fertilizers improved fruit biomass accumulation (MALGORZATA et al. 2010).

Results from the current study show that the fruit juice $\mathrm{pH}$ was the highest in GD. The improvement of fruit $\mathrm{pH}$ quality may be related to an improvement in the production of the plants, which might favor producing better quality fruit. The control treatment performed lowest in regard to fruit $\mathrm{pH}$ which might be connected to the stage of ripeness in the fruit since fruit parameters, such as the $\mathrm{pH}$ value, are related to the maturity stage of the fruit (JUROSZEK et al., 2009). Higher $\mathrm{pH}$ values were recorded (between 6.28 and 6.53), for watermelon when the organic manures varied (MASSRI; LABBAN 2014).

Fruit juice content is an important parameter in processing fruit because it is related to size (MONERUZZAMAN et al., 2011). The juice content is the percentage of water contained in the watermelon fruit. Watermelons are very juicy with a juice content of over 90\% (ROSNAH et al., 2010). The control treated fruit measurements show a higher moisture content than some poultry manure and vermicompost treatments, which was because unripe fruit can produce more water than ripe fruit. This observation is in agreement with the reports of 
FAO, (1989), that stated unripe watermelon has high moisture content, thus the weight of the fruit is heavier. At a complete maturity stage, the water content of the fruit is reduced, thus the weight of fruit consequently becomes lighter. In a study conducted on watermelon, it was reported that the juice percentage was the highest for sheep manure $(92.4 \%)$ treated plants followed by poultry manure $(91.43 \%)$, pigeon manure and control treated plants (90.99\% and $90.58 \%$ respectively). The average juice content of watermelon fruit was between 93 to 94.5\% (Figure 2A). These values were in agreement with that of USDA, (2003).

The colors in fruit and vegetables echo the presence of biologically active substances and antioxidants that have been reported to promote good health (MONERUZZAMAN et al., 2012). Plants treated with moringa extract, as a biostimulant, show high anthocyanin content, which is supported with the findings of Khandaker et al. (2012), who reported that the anthocyanin content was increased in $\mathrm{H}_{2} \mathrm{O}_{2}$ treated wax apple fruit. Moreover, total anthocyanins were similar for all treatments but tended to increase in the organic treatments (PANICKER; SIMS 2009). A study also reported that treatment with poultry manure had no effect on the presence of anthocyanins in the leaves of Ocimum gratissimum (OSUAGWU; EDEOGA 2012).

The total soluble solids determine the maturity standards and affect consumer acceptability (KHANDAKER et al., 2011). Fruit sweetness, is the most important quality factor in watermelon fruit and is related to the level of total soluble solids (TSS) (MAYNARD 2001). Data recorded for TSS did not vary amongst treatments statistically $(\mathrm{P} \leq 0.05)$, however, cow dung had the highest value of TSS and the control treatment had the least value. These observations, to some extent, are in agreement with the arguments of some studies where they verified that applying nitrogen rich organic fertilizers provided significant increases in the TSS content of melon plant fruit (SRINIVAS; PRABHAKAR 1984). All of the plants treated with organic matter had TSS ranges of 8.32-10.24 ${ }^{\circ}$ BRIX. These results indicate that organic matter improves the quality of watermelon fruit. This observation is based on the United States Standards of Watermelons grades (USDA, 1978) which indicate that watermelons with $8{ }^{\circ}$ BRIX TSS are good quality fruit. The ash percentages in this study range between $0.51-0.58 \%$ in treated plants and were noted since watermelon fruit is made up of 0.5\% Ash (Slavery, 1974). The results of this study are not in agreement with the findings of other reports which stated that ash content was not significantly affected by organic fertilizers tested on Chloris gayana (YOSSIF; IBRAHIM 2013), Results in Table 3 show that antioxidant scavenging activities increased with the application of different organic matter. Other research had similar findings about this higher antioxidant activity which was recorded when organic fertilization was compared to mineral fertilization in fresh jujubes (WU et al. 2013). The best radical inhibited activity percentages were found at $100 \mathrm{ug} / \mathrm{ml}$ and $50 \mathrm{ug} / \mathrm{ml}$ in plants treated with moringa extract, when compared with the standard used (Quercetin), which might be in connection with the effects of phenolic compound derivatives in moringa extract as a precursor for the synthesis of flavonoid structures and, as such, related to the increased antioxidant activity. OTHMAN et al. (2007) reported that reaction mixtures (fruit extract) consisting of $20 \mu \mathrm{g} / \mathrm{ml}-100$ $\mu \mathrm{g} / \mathrm{ml}$ showed better antioxidant activity. Flavonoids enhanced antioxidant activity (ABDALAH, 2013). The lowest levels of antioxidant scavenging activity were observed in the absence of organic matter. Therefore, it is sufficient to suggest that elements in the organic matter correlate to an increase in the scavenging activities of watermelon fruit. These results are not in agreement with several findings from other researchers who reported that mineral nutrition has little or no effect on the improvement of the polyphenols and antioxidants in some plants (PAVLA; POKLUDA, 2008).

It has been established that watermelon fruit contain high amounts of minerals such as $\mathrm{Mg}, \mathrm{K}, \mathrm{Zn}$ $\mathrm{Ca}, \mathrm{P}$, and $\mathrm{Fe}$, and other nutrients (OYOLU, 1977). The results revealed that all organic matter used in this study resulted in an improvement of the nutrient content of the watermelon fruit. This might be due to the organic material used which increased the soil's available macro and micro nutrient status. Poultry manure and vermicompost, as reported, have high NPK (AGBEDE et al., 2008) which stands out from other treatments in improving Potassium, Magnesium and Iron content in the soil. Organic material added to the soil increases the nutrient content of radish plants due to the beneficial effects of organic matter in improving soil's nutrition status, particularly the formation of nitrogen in the soil (WAFAA et al., 2015). Plants treated with moringa extract increase the sodium and copper content of watermelon fruit. This is supported by previous research that reported moringa extract is comprised of a high combination of important minerals, vitamins, beta-carotene, essential amino acids and many phenolics which 
provide a rare and rich combination of flavonoid pigments with several zeatin (ANWAR et al., 2007). There is a positive correlation between flavonoids and antioxidant activity in fruit (KHANDAKER et al. 2011).

\section{CONCLUSIONS}

Watermelon crops treated with vermicompost improve chlorophyll content, chlorophyll fluorescence and stomatal conductance.

Vermicompost also enhances fruit weight and nutrient content.

Cow dung improves internal carbon dioxide, rind thickness and TSS.
Fruit juice content and the juice's $\mathrm{pH}$ were significantly improved with the application of goat dung.

Moringa leaves extract improves the antioxidant scavenging activities of plants. However, it has been proved that the application of vermicompost significantly improves growth, yield and the quality of watermelon.

\section{ACKNOWLEDGEMENT}

We greatly thank the Research Management, Innovation \& Commercialization Centre (RMIC), of Universiti Sultan Zainal Abidin (UniSZA), Terengganu, Malaysia for its support in the writing and publication of this research.

RESUMO: Este estudo foi desenhado para avaliar os efeitos de diferentes tipos de matéria orgânica sobre a qualidade e propriedades bioquímicas da melancia vermelha sem sementes. A pesquisa foi um experimento de fator único, que envolveu seis (6) tratamentos e quatro (4) repetições. Melancia cultivada e colhida de cinco (5) diferentes fontes de matéria orgânica, nomeadamente; vermicomposto (VC), esterco de galinha (PM), estrume de vaca (CD), esterco de cabra (GD) e extrato de folhas de moringa (MLE), nas doses de 10 ton, 20 ton, 30 ton, 30 ton e $3000 \mathrm{~L}$ ha-1, respectivamente, foram utilizados neste estudo. Os resultados revelaram que o tratamento do vermicomposto melhorou o teor de clorofila, a fluorescência da clorofila, a condutância estomática, o dióxido de carbono interno, a taxa fotossintética líquida, o peso do fruto e o teor de nutrientes minerais da melancia. A aplicação de esterco bovino reduziu a espessura da casca e aumentou o TSS e a atividade antioxidante da melancia. $\mathrm{O}$ tratamento com esterco de cabra afetou significativamente o tamanho do fruto, o teor de suco e o teor de $\mathrm{pH}$ do suco de fruta da melancia. Os tratamentos com esterco de galinha (PM) e extrato de moringa (MLE) resultaram no maior teor de antocianina de todas as melancias. Apesar de toda a matéria orgânica, em seus meios únicos, melhorar a qualidade da melancia vermelha sem sementes, $o$ estudo mostra que a aplicação do vermicomposto apresentou melhor crescimento, rendimento e melhora na qualidade da melancia.

PALAVRAS CHAVE: Adubo. Qualidade. Propriedade bioquímica. Melancia.

\section{REFERENCES}

ABDEL-MAWGOUD, A.M.R.; TANTAWAY, A.S.; MAGDA, M.; HABIB A.M. Seaweed extract improves growth, yield and quality of different watermelon hybrids. Research Journal of Agriculture and Biological Science, v.6, p.161-168, 2010.

ABDULLAH, M.Z.; GUAN, L.C.; LIM AND K.C.; KARIM A.A. The applications of computer vision and tomo- graphic radar imaging for assessing physical properties of food. Journal of Food Engineering, v. 61, p.125-135, 2004. https://doi.org/10.1016/s0260-8774(03)00194-8

AGBEDE, T.M.; OJENIYI AND, S.O.; ADEYEMO A.J. Effect of poultry manure on soil physical and chemical properties, growth and grain yield of sorghum in Southwest, Nigeria. American Eurusion Journal of Sustainable Agriculture, v. 2, p.72-77, 2008.

ALABI, D.A. Effects of fertilizer phosphorus and poultry droppings treatments on growth \& nutrient component of pepper (Caspicum annum). Journal of Plant Nutrition, v.17, p.127-146, 2006. 
ALI, A.M.; KELLY W.C. The effects of interfruit competition on the size of sweet pepper (Capsicum annuum) fruits. Scientia Horticulturae, v.52, p. 69-76, 1992. https://doi.org/10.1016/0304-4238(92)90009-2 ANGHINONI, I. Fatores que interferem na eficiência da adubação fosfatada. In: YAMADA, T.; ABDALLA, S. R. S. (Eds).Fósforo agric. bras.. Piracicaba: POTAFOS, p. 537-562, 2004.

ANWAR, F.; LATIF S.; ASHRAF M.; GILANI A.H. Moringa oleifera: A food plant with multiple medicinal uses. Phytothermal Research, v.21, p.17-25, 2007. https://doi.org/10.1002/ptr.2023

BAKER, J.T.; EARHART, D.R.; BAKER, M.L.; DAINELLO F.J.; HABY V.A. (Interactions of poultry litter, polyethylene mulch, and floating row covers on triploid watermelon. HortScience, v.33 (5), p. 810-813, 1998. https://doi.org/10.21273/hortsci.33.5.810

Blois, M.S. Antioxidant determinations by the use of a stable free radical. Nature, v.181, p.1199-1200, 1958. https://doi.org/10.1038/1811199a0

DAUDA, S.N.; ALIYU, L.; CHIEZEY,U.F. Effect of variety, seedling age and poultry manure on growth and yield of garden egg (Solamun gilo L.). Nigerian Academic Forum, v.9, p.88-95, 2005.

EFTHIMIADOU, A.; BILALIS, D.; KARKANIS, A.; FROUDWILLIAMS, B. Combined organic/inorganic fertilization enhance soil quality and increased yield, photosynthesis and sustainability of sweet maize crop. Australian Journal of Crop Science, v. 4, n. 9, p. 722-729, 2010.

FAO (FOOD AGRICULTURAL ORGANIZATION). Hunger and malnutrition posted in http://wwwfaoorg/news/story/en/item/ 41994/icode/\%22\%3EFAO, 2015.

FAO (FOOD AND AGRICULTURE ORGANIZATION). Prevention of Post-harvest Food Losses Fruits, Vegetables and Root Crops a Training Mannual http://wwwfaoorg/docrep/T0073E/T0073E02htm\#47\%20Respiration, 1989.

FUGLIE, L.J. The Miracle Tree: Moringa oleifera: Natural Nutrition for the Tropics, The multiple Attributes of Moringa. p 172, 2000.

HEGAZI, E.S.; EL-SONBATY M.R.; EISSA M.A. Effect of organic bio-fertilization on vegetative and flowering of Picual olive trees. World Journal of Agriculture Science, v.3, p. 210-217, 2007.

INTHICHACK, P.; NISHIMURA Y., FUKUMOTO, Y. Effect of Diurnal Temperature Alternations on Plant Growth and Mineral Composition in Cucumber, Melon and Watermelon. Pakistan Journal of Biological Sciences, v. 17, n. 8, p. 1030-1036, 2014. https://doi.org/10.3923/pjbs.2014.1030.1036

IITA. Growing watermelon commercially in Nigeria- an illustrated guide International Institute of Tropical Agriculture (IITA). pp1-16. 2013. https://doi.org/10.19103/as.2018.0043.15

INUWA, H.M.; AINA, V.O.; GABI, B.; AIMOLA I.; THOMPSON V. Determination of Differences in Nutrient Composition of Citrullus vulgaries (Water Melon) Fruits after Plucking. British Journal of Dairy Science, v.2, p. 27-30, 2011.

JACKSON, M. L. Soil chemical analysis. Prentice Hall of India Pvt Ltd, New Delhi, India. 1973.

JOHN, L.W.; JAMER, D.B.; SAMUEL, L.T.; WARNER L.W. Soil Fertility and Fertilizers: An Introduction to Nutrient Management. Person Education, Delhi, 106-153, 2004.

JUROSZEK, P.; LUMPKIN, H.M.; YANG, R.Y.; LEDESMA D.R.; MA C.H. Fruit quality and bioactive compounds with antioxidant activity of tomatoes grown on-farm: comparison of organic and conventional management systems. Journal of Agriculture and Food chemistry, v.57, p.1188-1194, 2009. https://doi.org/10.1021/jf801992s 
KENNY, I. J.; PORTER D. R. Relative rind toughness among watermelon varieties. Proceding of American Society of Horticultural Science, v.38, p.537-540, 1941.

KHANDAKER, M. M.; BOYCE, A. N.; NORMANIZA O.; FARUQ, G.; MOTIOR RAHMAN M.; SOFIAN-AZIRUN M. Fruit development, pigmentation and biochemical properties of wax apple as affected by localized application of GA3. Brazilian Archives of Biology and Technology, v. 56, n. 1, p.11-20, 2013. https://doi.org/10.1590/s1516-89132013000100002

KHANDAKER, M. M.; BOYCE, A.N.; OSMAN, N.; HOSSAIN A.B.M.S. Physiochemical and phytochemical properties of wax apple (Syzygium samarangense [Blume] Merrill \& LM Perry var jambu madu) as affected by growth regulator application. Scientific World Journal, v.2012, p.1-13, 2012. https://doi.org/10.1100/2012/728613

KHANDAKER, M.M.; HOSSAIN, A.S.; OSMAN N.; BOYCE A.N. Application of girdling for improved fruit retention, yield and fruit quality in Syzygium samarangense under field conditions. International Journal of Agriculture and Biology, v. 13, p. 18-24, 2011.

KHANDAKER, M. M., JUSOH N., RALMI N. H. A. AND ISMAIL, S. Z. The effect of different types of organic fertilizers on growth and yield of Abelmoschus esculentus L. Moench (okra). Bulgarian Journal of Agriculture Science, v. 23, n. 1, p. 119-125, 2017. https://doi.org/10.21275/art20164171

MALGORZATA, B.; KARANATSIDIS, G.; SAPUNDZHIEVA, K,; NIKOLOVA, V. Effect of organic fertilization on growth and yield of pepper plants (Capsicum annuum L) Folia. Horticulture Annal, v. 22, n.1, p.3-7, 2010. https://doi.org/10.2478/fhort-2013-0143

MASSRI, M.; LABBAN, L. Comparison of different types of fertilizers on growth , yield and quality properties of watermelon ( Citrllus lanatus ). Agricultural Sciences, v. 5, p.475-482, 2014. https://doi.org/10.4236/as.2014.56048

MAYNARD, D. N. Uses and Nutritional Composition http://watermelonsifasufledu/Uses and Nutritional Compositionhtm. 2001.

MCDONOUGH, A.A.; NGUYEN, M. T. How does potassium supplementation lower blood pressure? American journal of physiology Renal physiology. v. 302, n. 9, p.1224-1225, 2012. https://doi.org/10.1152/ajprenal.00429.2011

MONERUZZAMAN, K. M.; FARUQ, G.; MOTIOR, M,R.; SOFIAN- AZIRUN, M.; BOYCE, A.N. The Influence of 1-Triacontanol on the Growth, Flowering and Quality of Potted Bougainvillea Plants (Bougainvillea glabra var. Elizabeth angus ) Under Natural Conditions. Scientific World Journal, v. 2013, p.1-12, 2013. https://doi.org/10.1155/2013/308651

MONERUZZAMAN, K.M.; AL-SAIF; ALEBEDI, A.M.; HOSSAIN, A.I; NORMANIZA, A. B. M. S.; BOYCE, A.N. An evaluation of the nutritional quality evaluation of three cultivars of Syzygium samarangense under Malaysian conditions. African Journal of Agricultural Research, v.6, n. 3, p. 545-552, 2001.

OJO, J.; OLOWOAKE, A. A.; OBEMBE, A. Efficacy of organomineral fertilizer \&un-amended compost on the growth and yield of watermelon (Citrullus lanatus Thumb) in Ilorin Southern Guinea Savanna zone of Nigeria. International Journal of Recycle and Organic Waste Agriculture, v.3, p.121-125, 2014. https://doi.org/10.1007/s40093-014-0073-z

OSUAGWU, G.G.E. The effect of rate of application of poultry manure on the phenols, flavonoid and steroid potential of the leaves of Ocimum gratissimum. Journal of Sustainable Agricultural Environment. v.10, p.106 - 111, 2008. 
OTHMAN A, ISMAIL A, GHANI NA, ADENAN I. Antioxidant capacity and phenolic content of cocoa beans. Food Chemistry, v.100, p.1523-30, 2007. https://doi.org/10.1016/j.foodchem.2005.12.021

OYOLU, C. A quantitative and qualitative study of seed types in egusi (Colocynthis citrullus L). Tropical Science, v.19, p.55-62, 1977. https://doi.org/10.17660/actahortic.1977.53.38

PANICKER, G. K.; SIMS, C.A.; SILVA, J.L.; MATTA, F.B.; SPIERS, J.M. Effect of worm castings, cow manure, and forest waste on yield and fruit quality of organic blueberries grown on a heavy soil. Acta Horticulture, v.841, p.581-584, 2009. https://doi.org/10.17660/actahortic.2009.841.88

PAVLA, B.; POKLUDA, R. Influence of alternative organic on the antioxidant capacity in head cabbage and cucumber. Notulae Bot Horti Agrobot Cluj- Napoca, v.36, p. 63-67. 2008.

RAKESH, J.; SINGH, J.; VIG, A.P. Vermicompost as an effective organic fertilizer and biocontrol agent: effect on growth, yield and quality of plants. Review on Environmental Science \& Biotechnology, v.14, p.137-159, 2015. https://doi.org/10.1007/s11157-014-9347-1

RAPHAEL, A.S.; MOSHE, F.; STEVE, A.; RUTH, B.A. Effect of synthetic auxins on fruit development of 'Bing' cherry (Prunus avium L). Science Horticulture. v.114, p. 275-280, 2007.

https://doi.org/10.1016/j.scienta.2007.07.010

RASMUNA, M.; MOHD, M.; MOHD, M.A.; SITI, Z.P. Kajian Menanda Aras Teknologi Pengeluaran Tembikai Laporan Projek Sosioekonomi, Pusat Penyelidikan Ekonomi dan Sains Sosial, MARDI, Serdang. 2015.

RICE, R.P.; RICE, L.W.; TINDAL, H.D. Fruit and Vegetable Production in Africa. Macmillan Publications, pp: 221-2, 1986.

ROCHA, M.C.; R. DELIZA, R.; F.M. CORRÊA, F.M.; CARMO, M.G.F.; ABBOUD, A.C.S. A study to guide breeding of new cultivars of organic cherry tomato following a consumer-driven approach. Food Research International, v.51, p. 265-273, 2013. https://doi.org/10.1016/j.foodres.2012.12.019

RODRIGUEZ-SAONA, L.E.; GIUSTI, M.M.; WROLSTAD, R.E. Color and pigment stability of red radish and red fleshed potato anthocyanins in juice model systems. Journal of Food Science, v.64, p.451-456, 1999. https://doi.org/10.1111/j.1365-2621.1999.tb15061.x

ROSNAH, S.; YAU, E.W; NORAZIAH, M.; CHIN, N.L.; OSMAN, H. Physico-chemical compositions of the red seedless watermelons (Citrullus lanatus). International Food Journal, v.17, p.327-334, 2010.

SCHIPPERS, R.R. African Indigenous Vegetable, An Overview of the Cultivated species. Chatthan, U.K., N.R/ACO, EU. pp: 56-60, 2000

SENDURKUMARAN, S.; NATRAJAN, S.; THAMBURAJ, S. Effect of organic and inorganic fertilizers on growth, yield and quality of tomato. South Indian Horticulture, v.46, p. 203-205, 1998.

SILVIA, P.S.L.; RODRIGUES, V.L.P.; MEDEIROS, J.F.; DEAQUINO, B.F.; DA SILVA, J. Yield and quality of melon fruits as a response to the application of nitrogen and potassium doses. Revista Caatinga, v.20, n. 2, p.43-49, 2007.

SINGH, S. Effect of elevated levels of carbon dioxide and light on mycorrhiza. Mycorrhiza News, v.16 (4), p. 2-11, 2005.

SLAVERY, W. Chemical Composition of Watermelon. pp: 390-412. 1974. 
SRINIVAS, K.; PRABHAKAR, B.S. Response of muskmelon (Cucumis melo L) to varyind lends of spacing and fertilizers. Singapore Journal of Primary Industry, v.2, p.36-61, 1984.

STOLZ, H.; STOLZE, M.; JANSSEN, M.; HAMM, U. Preferences and determinants for organic, conventional and conventional-plus products-The case of occasional organic consumers. Food Quality Preference, v.22, p.772-77, 2011. https://doi.org/10.1016/j.foodqual.2011.06.011

TADMOR, Y.; BURGER, J.; YAAKOV, I.; FEDER, A.; LIBHABER, S.E.; PORTNOY, V.; MEIR, A.; TZURI, G.; SA'AR, U.; ROGACHEV, I.; AHARONI, A. Genetics of flavonoid, carotenoid, and chlorophyll pigments in melon fruit rinds. Journal of Agricultural and Food Chemistry, v. 58, n.19, p.10722-10728, 2010. https://doi.org/10.1021/jf1021797

USDA, US DEPT. AGR. Nutritional Composition of Watermelon http://watermelonifasufledu/Uses and Nutritional Composition. 2003

USDA, US DEPT. AGR. US standards for grades of watermelons http://watermelonifasufledu/Uses and Nutritional Composition. 1978.

WAFAA, H.M.; SEOUD, I.I.A.; ELALHADAD, W.A.A. Effect of organic materials and inorganic fertilizers on the growth, mineral composition and soil fertility of radish plants (Raphine sativus) Grown in Sandy Soil.

Middle East Journal of Agriculture, v.4, p.77-87, 2015.

WU, C. S.; GAO, Q.H.; KJELGREN, R.K.; GUO, X.D.; WANG, M. Yields, Phenolic Profiles and Antioxidant Activities of Ziziphus jujube Mill In response to different fertilization Treatments. Molecule, v.18, p. 1202912040, 2013. https://doi.org/10.3390/molecules181012029

YOSSIF, A. M.; IBRAHIM, Y.M. Effect of Organic and Inorganic Fertilizers on Proximate Analysis of Rhodes Grass ( Chloris gayana L Knuth). Universal Journal of Plant Science, v.1, p.137-140, 2013.

ZHANG N.; REN Y.; SHI, Q. Effect of Vermicompost on Quality and Yield of Watermelon. Journal of China Vegetables, v.1, n. 6, p.76-79, 2011. 